Reference NBS

Publi -

cations

NBSIR 81-1639

EFFECTIVE THERMAL CONDUCTIVITY OF A GLASS FIBERBOARD STANDARD REFERENCE MATERIAL

David R. Smith

Jerome G. Hust

Thermophysical Properties Division

National Engineering Laboratory

National Bureau of Standards

Boulder, Colorado 80303

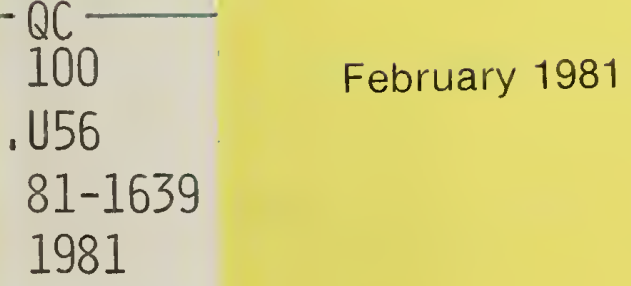





\section{EFFECTIVE THERMAL CONDUCTIVITY OF A GLASS FIBERBOARD STANDARD REFERENCE MATERIAL}

David R. Smith

Jerome G. Hust

Thermophysical Properties Division

National Engineering Laboratory

National Bureau of Standards

Boulder, Colorado 80303

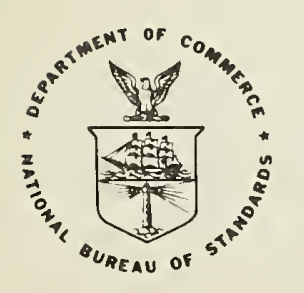

U.S. DEPARTMENT OF COMMERCE, Malcolm Baldridge, Secretary 

CONTENTS

Page

Introduction . . . . . . . . . . . . . . . . . . 1

Apparatus and Specimen Characterization . . . . . . . . . . . 1

Results ........................... 3

Discussion . . . . . . . . . . . . . . . . . . 5

References (Annotated Bibliography) . . . . . . . . . . . 12 



\section{Effective Thermal Conductivity \\ of a Glass Fiberboard Standard Reference Material}

David R. Smith and Jerome G. Hust

This paper* describes the results of thermal conductivity measurements on NBS SRM 1450 glass fiberboard insulation (1970 lot) at temperatures from $87 \mathrm{~K}$ to $340 \mathrm{~K}$. The measurements were performed in an atmosphere of dry nitrogen at a pressure near $84 \mathrm{kPa}(630 \mathrm{~mm} \mathrm{Hg})$. The results are analyzed and compared to NBS certification data and to literature data for similar material. An annotated bibliography of literature sources is included.

Key words: Glass fiberboard; insulation; low-temperature; standard reference material; thermal conductivity.

\section{Introduction}

Previous work on effective thermal conductivity of several lots of glass fiberboard Standard Reference Material (designated as SRM 1450) has been reported [1] for specimens in air at local atmospheric pressure and at mean temperatures of $255 \mathrm{~K}$ to $330 \mathrm{~K}$. Results of measurements are reported here for the 1970 lot of SRM 1450 fiberboard for specimen temperatures covering the range from $87 \mathrm{~K}$ to $340 \mathrm{~K}$, in an atmosphere of dry nitrogen gas at $84 \mathrm{kPa}$ (630 $\mathrm{mm} \mathrm{Hg}$ ), local atmospheric pressure.

\section{Apparatus and Specimen Characterization}

A commercial guarded-hot-plate thermal conductivity instrument was extensively modified [2] to permit efficient use of cryogenic or refrigerated coolants, to obtain greater stability of controlled temperatures, and to achieve

*This work was done for the Department of Energy, Oak Ridge Operation, Oak Ridge, TN 37830, under Interagency Agreement DoE No. DE-AI05-780R05965. 
lower imprecision and uncertainty of measurements. This apparatus was designed to measure heat transfer through a pair of specimens surrounding the horizontal hot plate in the typical double-sided guarded hot plate configuration (ASTM STM C-177).

The pair of specimens studied were disks of nominal $20 \mathrm{~cm}$ ( 8 in) diameter and $2.6 \mathrm{~cm}(1.0 \mathrm{in})$ thickness. They were cut from larger slabs measuring 28 by $30 \mathrm{~cm}$, as received from the National Bureau of Standards, Office of Standard Reference Materials stock. The pair was chosen on the basis of near equality of area densities $\left(0.322 \mathrm{~g} / \mathrm{cm}^{2}\right.$ and $\left.0.317 \mathrm{~g} / \mathrm{cm}^{2}\right)$. The thickness, $\Delta x$, of each specimen was determined during the conductivity measurement by three quartz spacer tubes positioned at three equidistant points around the perimeter; small notches were cut in the edge of each specimen to receive the spacers. The thickness during measurement was $2.59 \mathrm{~cm}$ and the resulting volume density was $123 \mathrm{~kg} / \mathrm{m}^{3}$. No correction for thermal contraction of the quartz spacers was necessary (less than 0.01 percent).

All hot plate/cold plate surfaces facing the specimens were black anodized aluminum. The cold surfaces were electrically heated, temperature-controlled plates, cooled by resistive thermal contacts with fluid-cooled copper plates; thus the cold surfaces of the specimens could be brought to a temperature near that of the coolant, or raised in temperature, as desired. The main heater (metered section) was a disk $10.16 \mathrm{~cm}$ in diameter separated by a $1.6 \mathrm{~mm}$ gap from the annular guard of $5.1 \mathrm{~cm}$ width. A concentric, cylindrical outer guard surrounded the stack of auxiliary heaters, specimens and main heater. It established a temperature gradient approximating that of the stack about $2 \mathrm{~cm}$ away from the stack edge surfaces. 
Temperature controllers were used to regulate conditions in the inner and outer guards and to establish steady temperatures in the auxiliary heaters at the cold sides of the specimens. The offset signal for the inner-guard controller was developed by a 20-pair thermopile of type E thermocouples, with alternate junctions on opposite sldes of the gap separating the main and innerguard heater plates.

Type $\mathrm{K}$ thermocouples (32 gauge) for deternining temperatures of the specimen faces, positioned at the center and near the gap surrounding the main heater, were varnished to the surfaces of the hot and auxiliary plates over a length of $15 \mathrm{~cm}$. These thermocouples were also thermally tempered by means of $15 \mathrm{~cm}$ of wire wrapped and varnished to copper lugs attached to the periphery of the hot and auxiliary plates.

Type $\mathrm{K}$ thermocouple wire was calibrated using a calibrated platinum resistance thermometer and baths of liquid helium, liquid nitrogen, dry-ice-andalcohol, ice-water, room-temperature water, and boiling water. The departures from the standard tabular values* of emf vs. temperature were represented by a 3-terin polynomial and a corrected calibration curve was formulated for the particular spools of thermocouple wire used.

The dc power, Q, for the main heater was obtained from a constant current power supply of better than 0.01 percent stability and accuracy. The power in the metered heater was found from the product of voltage drop, V, across the heater and the current, I, through the heater.

\section{Results}

Measurements of heat flow and of temperatures of the hot and cold surfaces were performed at mean temperatures from $100 \mathrm{~K}$ to $325 \mathrm{~K}$ with temperature

\footnotetext{
*Thermocouple Reference Tables based on IPTS-63, NBS Monograph 125, March, 1974.
} 
differences of about $25 \mathrm{~K}$ (gradient approximately $1 \mathrm{deg} / \mathrm{mm}$ ). Larger gradient runs (up to $\Delta T=100 \mathrm{~K}$ ) were taken at some temperatures to search for the presence of non-conductive heat transfer mechanisms. The metered area, $A_{m}$, was taken to be that contained within the $10.32 \mathrm{~cm}$ diameter circle including the main heater and one-half of the surrounding gap. The area through which the metered heat energy flows through the two matched specimens $2 A_{m}$. This area was corrected for thermal expansion (less than 0.7 percent).

The mean thermal conductivity, $k$, was computed according to $\bar{k}=\frac{Q}{A} \frac{\Delta X}{\Delta T}=$ $\frac{V I}{2 A_{m}} \frac{\Delta X}{\left(T_{2}-T_{1}\right)}$, where $T_{2}$ and $T_{1}$ are the average nis: and cold side temperatures, rasurtively. The resulting data set of values $\bar{k}, Q, T_{1}$, and $T_{2}$ were then functionally represented using a thermal conductivity integral (TCI) fitting technique* to yield the thermal conductivity as a continuous function of temperature over the range from the lowest value of $T_{1}(87 \mathrm{~K})$ to the highest value of $\mathrm{T}_{2}(340 \mathrm{~K})$. This resulted in the values of the parameters, $\mathrm{A}_{i}$, in the equation $k=\sum_{i=1}^{4} A_{i} T^{i}$. This technique is valid only to the extent that the mechanisms of heat transfer are conductive in nature (as opposed to) direct radiation or convection). Deviations from this condition can be detected by searching for systematic trends in the deviations of the fitted data as a function of boundary conditions. The principle variable examined for such deviations was $\Delta \mathrm{T}=\mathrm{T}_{2}-\mathrm{T}_{1}$. It was noted that no trend exists in the deviations, within experimentil scatter, for temperature differences ranging Erom $25 \mathrm{~K}$ to $100 \mathrm{~K}$.

*Hust, J. G. and Lankford, A., Comments on the Measurement of Thermal ConducEivity and Presentation of the Thermal Conductivity Integral Method, to be ablished in Cryogenics. 
The values of $k$ vs. temperature obtained by means of this technique for the SRM specimens are given in Table 1 and plotted in Fig. 1 (solid line). The values of $\bar{k}$ are also plotted in Fig. 1 (circles) at the mean temperature, $\bar{T}$. The fact that the mean values of thermal conductivity, $k$, are consistent with the solid line for $\mathrm{k}$ at $\overline{\mathrm{T}}$ is indicative of the absence of appreciable nonconductive heat transfer mechanisms, $i . e .$, direct radiation and convection. Deviations between $\bar{k}$ and $k$ at $\bar{T}$ can also be caused by non-linear behavior of $k$ vs. T for just conductive heat transfer, but, in this case $k$ vs. $T$ is nearly linear. Table 2 gives the coefficients, $A_{i}$, and the range over which the fitted curve is valid. The TCI deviations, (TCI $\left.I_{\text {bs }}-T_{C I_{C a l c}}\right) \times 100 / T C I_{\text {obs }}$, between the data (obs) and the fitted (calc) curve are given in Fig. 2 as a function of mean temperature. The horizontal bars indicate the temperature range for each measurement and the range of the TCI. A three term polynomial fit showed systematic deviations from the data at low temperature but the four term polynomial exhibits only random deviations.

\section{Discussion}

Previous NBS work [1] on the lot of insulation SRM's from which our specimens were taken resulted in certification data given by $k=A_{0}+A_{1} d+A_{2} T^{3}$ where $A_{0}=0.02052, A_{1}=1.303 \times 10^{-5}, A_{2}=4.015 \times 10^{-10}, \mathrm{~d}=\operatorname{density}\left(\mathrm{kg} / \mathrm{m}^{3}\right)$ and $T=$ absolute temperature $(K)$. The differences between the certification data and our results are shown in Fig. $2(+)$.

The previous work on this SRM 1450 performed at NBS/Washington [1] resulted in a different representation of the fitted curve, with only one temperature dependent term, while we find it necessary, because of our broad temperature 
range, to use the four term polynomial in temperature given earlier. Although a systematic difference exists (the certification values are larger over most of the range) between our data and the certification data, the agreement is within 1.5 percent over the whole range of temperature common to both investigations. Our estimated uncertainty of measurement is about 1 percent. The NBS certification data is uncertain by about 2 percent.

Other investigators [3-16] have reported the same trends in the dependence of $k$ on temperature for glass fiber insulations over a wide range of densities including our value. The characteristic differences of these insulations, such as binder or lubricant content, fiber size or atmospheric pressure actually present at each laboratory, are not known well enough to permit detailed statements about the agreement or disagreement between results. Comparisons of literature data $[1,8,10,12-14,16]$ to our equation are 111 ustrated in Fig. 3 . Research on SRM 1450 is being continued to determine the effects of specimen density and fill gas species and pressure on the effective thermal conductivity. Other parameters such as thickness and plate emittance will also be examined to further elucidate the nature of the heat transfer mechanisms present. 


\section{Table 1}

Thermal conductivity of fiberglass board (SRM 1450) versus temperature based on the fitted results of the present investigation.

\begin{tabular}{|c|c|c|c|}
\hline $\mathrm{T}(\mathrm{K})$ & $\begin{array}{c}\mathrm{k} \\
(\mathrm{mW} / \mathrm{m} \cdot \mathrm{K}) \\
\end{array}$ & $T(K)$ & $\begin{array}{c}\mathrm{k} \\
(\mathrm{mW} / \mathrm{m} \cdot \mathrm{K})\end{array}$ \\
\hline 87 & 10.51 & 160 & 18.96 \\
\hline 88 & 10.63 & 170 & 20.04 \\
\hline 89 & 10.75 & 180 & 21.10 \\
\hline 90 & 10.87 & 190 & 22.14 \\
\hline 91 & 10.99 & 200 & 23.16 \\
\hline 92 & 11.11 & 210 & 24.17 \\
\hline 93 & 11.23 & 220 & 25.16 \\
\hline 94 & 11.35 & 230 & 26.14 \\
\hline 95 & 11.47 & 240 & 27.11 \\
\hline 96 & 11.59 & 250 & 28.07 \\
\hline 97 & 11.71 & 260 & 29.03 \\
\hline 98 & 11.83 & 270 & 29.99 \\
\hline 99 & 11.95 & 280 & 30.95 \\
\hline 100 & 12.07 & 290 & 31.92 \\
\hline 110 & 13.26 & 300 & 32.90 \\
\hline 120 & 14.44 & 310 & 33.90 \\
\hline 130 & 15.60 & 320 & 34.93 \\
\hline 140 & 16.74 & 330 & 35.99 \\
\hline 150 & 17.86 & 340 & 37.09 \\
\hline
\end{tabular}




\section{Table 2}

$$
\begin{aligned}
& \text { Coefficients of the Least-Squares Fit: } k=\sum_{i=1}^{4} A_{i} T^{i} \\
& A_{1}=0.114622 \\
& A_{2}=0.149249 \times 10^{-3} \\
& A_{3}=-0.104388 \times 10^{-5} \\
& A_{4}=0.163799 \times 10^{-8} \\
& \text { Range: } \quad 87 \mathrm{~K} \leq \mathrm{T} \leq 340 \mathrm{~K}
\end{aligned}
$$




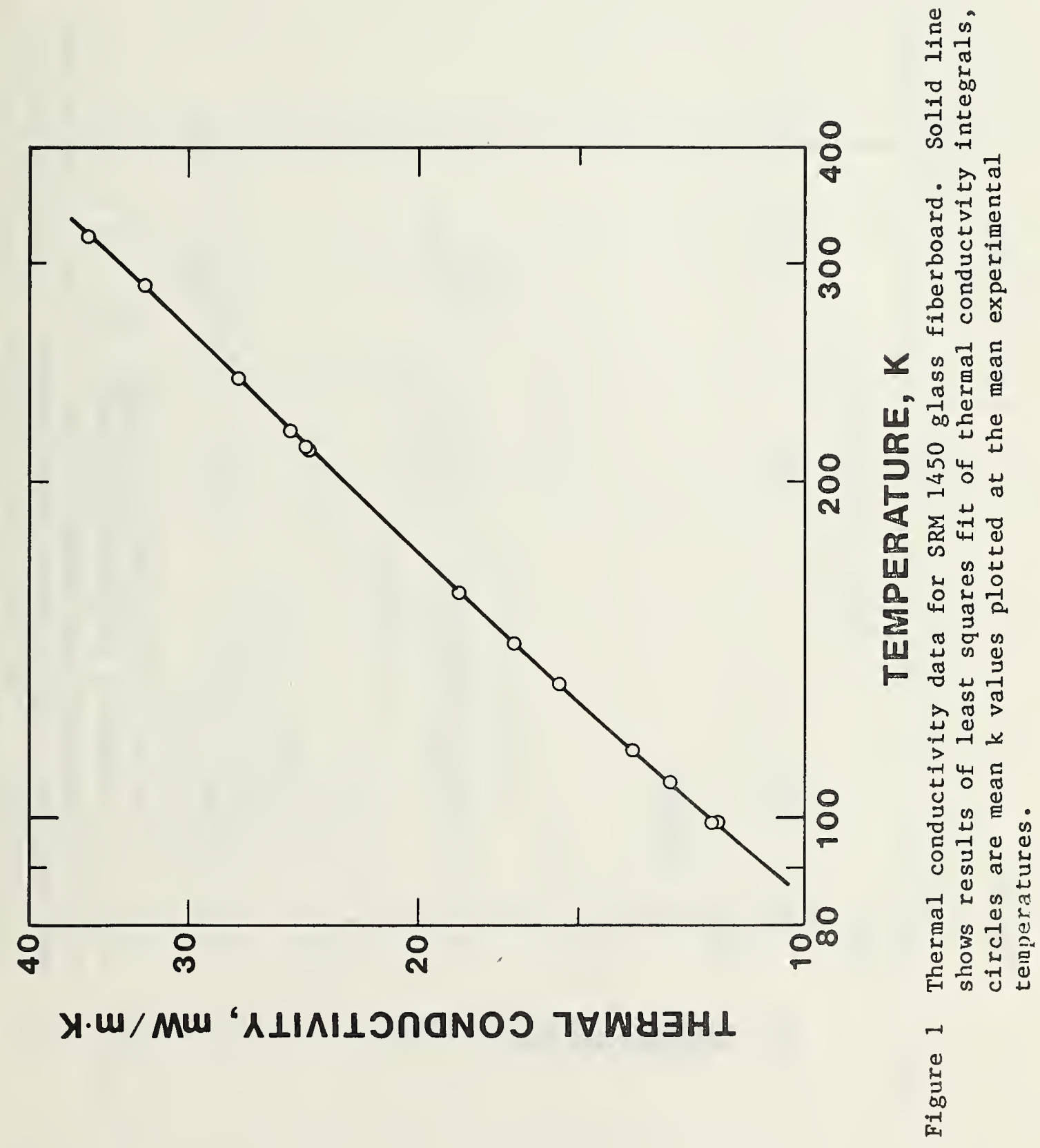




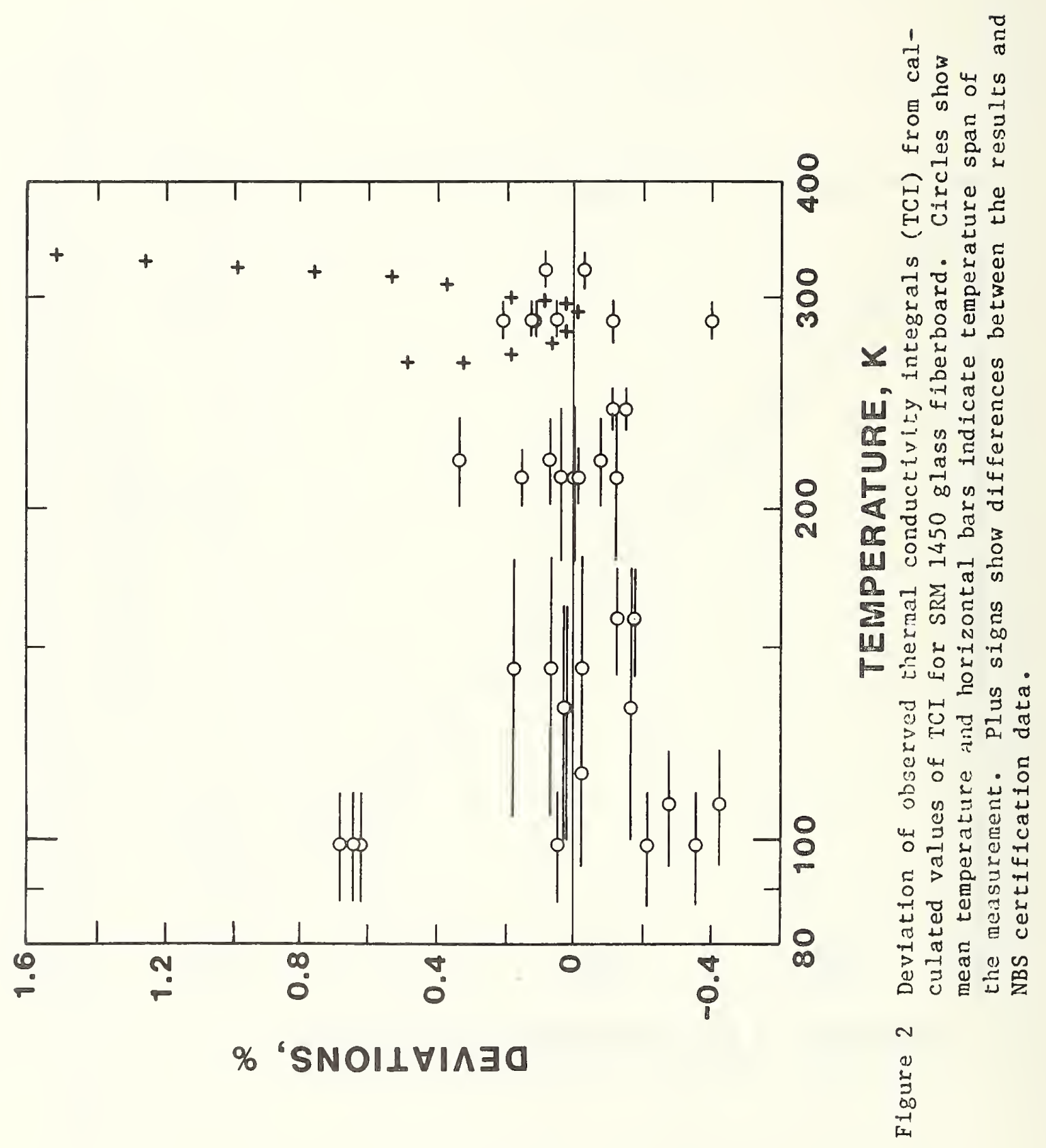




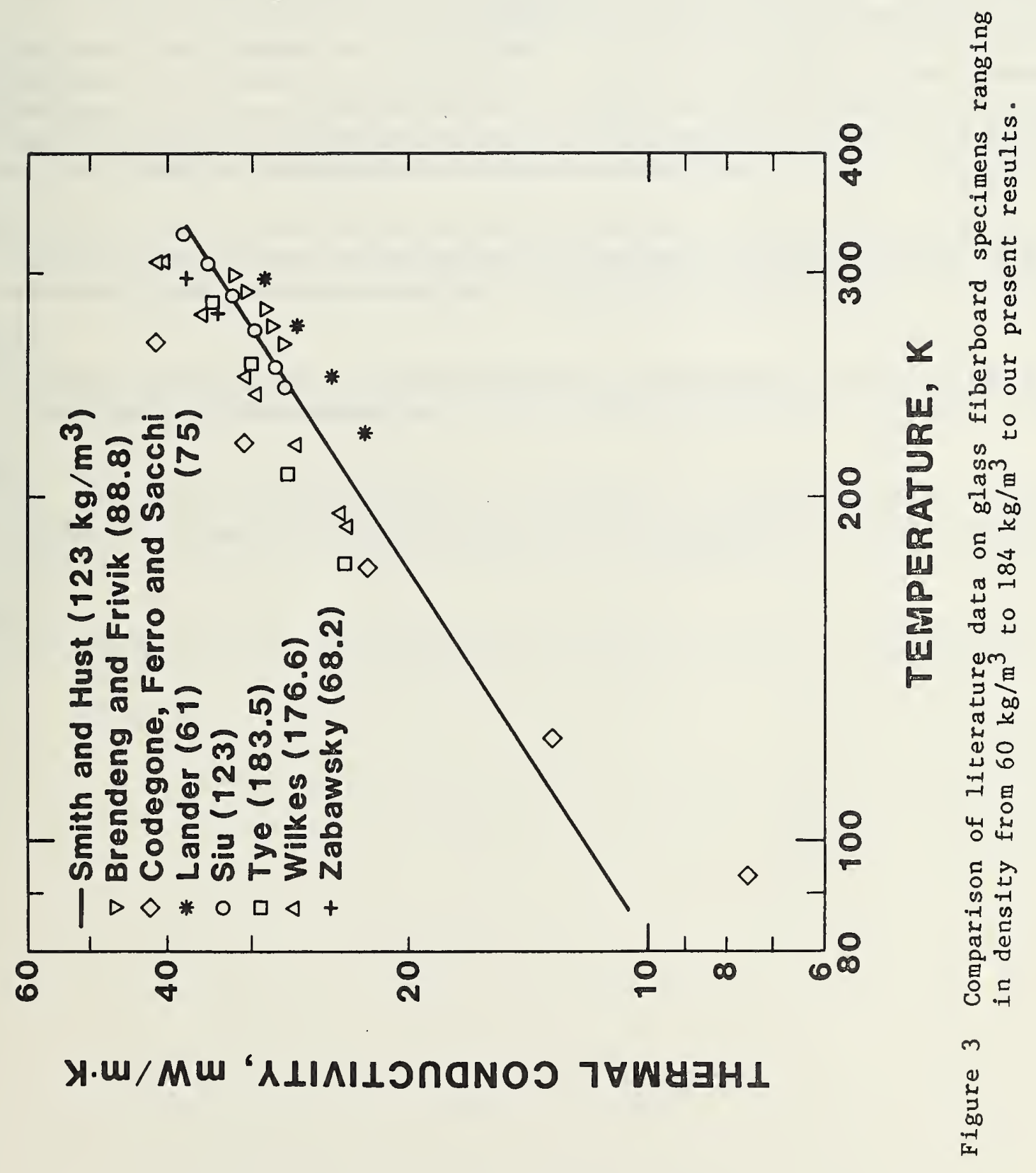


The references for this document and other papers of interest have been presented in the form of an annotated bibliography as an aid to the reader.

An extensive search has been made of the published literature relating to the effective thermal conductivity of fibrous glass insulation, in the range of densities characteristic of fiberglass boards. Of special interest to the authors are studies relating to the dependence of $k$ on temperature, density, gas pressure and species of fill gas. The format, given below, for this bibliography is designed to present the conclusions of each paper in a concise manner. Not all papers fit the format in 1 ts entirety but the format includes all the relevant types of information found in the majority of papers studied.

It is found that authors' abstracts are not sufficiently detailed in describing specific types of specimen characterization, experimental or theoretical studies and conclusions; therefore abstracts have not been listed in this work.

The units shown in the annotated bibliography are those given in the original article. SI units have been added in parentheses for convenience. 


\section{FORMAT FOR ANNOTATED BIBLIOGRAPHY}

\section{REFERENCE}

AUTHOR, TITLE, CITATION

\section{ANNOTATION}

PURPOSE

SPECIMEN

a) Thickness; b) Density; c) Fill Gas Species/Pressure; d) Fiber Diameter; e) Bonding Agent; f) Other Characterization

APPARATUS

a) Type; b) Heater Dimensions: Overall/test; c) Plate Orientation or Radial Axis; d) Thermometry; e) Calibration; f) Remarks

THEORY

a) Physical/Mathematical Models Including Assumptions; b) Calculational Techniques; c) Results

DATA

a) Temperature Range/Gradient; b) Content of Tables, Figures, and Equations; c) Uncertainty/Imprecision; d) Disputable Corrections to Measurements by Authors; e) Errata (by Author or Reviewer)

ANALYSIS

a) Comparisons; b) Heat Transfer Mode Separations; c) Conclusions 
[1] Siu, M. C. I., Fibrous Glass Board as a Standard Reference Material for Thermal Resistance Measurement Systems, in Thermal Insulation Performance, ASTM STP 718, D. L. McElroy and R. P. Tye, eds., American Society for Testing and Materials, 1980, pp. 343-360.

\section{PURPOSE}

Measurements on over 300 pairs of specimens and statistical analysis of data. Discussion on use of this material as an SRM.

SPECIMEN

a) I inch (25 mm) thick; b) 120 to $160 \mathrm{~kg} / \mathrm{m}^{-3}$; c) air/atmospheric

\section{APPARATUS}

a) NBS guarded hot plate;

b) 8 inches $(20 \mathrm{~cm}) \mathrm{sq} \cdot / 4$ inches $(10 \mathrm{~cm}) \mathrm{sq}$.

DATA

a) 255 to $330 \mathrm{~K} / 10 \mathrm{~K} / \mathrm{cm}$; d) approximately $0.3 \%$ imprecision and $1 \%$ uncertainty.

[2] Smith, D. R., Hust, J. G., and Van Poolen, L. J., A Guarded-Hot-Plate Apparatus for Measuring Effective Thermal Conductivity of Insulations Between $80 \mathrm{~K}$ and $350 \mathrm{~K}$ (to be published as an NBSIR).

PURPOSE

To describe in detail the modifications made to a commercial guarded hot plate apparatus for use as a certification device.

APPARATUS a) Guarded hot plate; b) 8 inches $(20 \mathrm{~cm}) / 4$ inches $(10 \mathrm{~cm})$ dia.;
horizontal; d) Type $\mathrm{K}(\mathrm{Cr}-\mathrm{Al})$ thermocouples; e) calibration measurements agreed to within $1 \%$ f) apparatus operated over the range approx. 80 to $350^{\circ} \mathrm{K}$ 
[3] Agrawal, K. N., Verma, V. V., An Apparatus for the Study of Heat and Mass Transfer Properties of Insulating Materials at Low Mean Temperatures, Indian J. Technology $\underline{7(1)}$, 4-8 (Jan 1969).

\section{PURPOSE}

Reports design of an apparatus for studying thermal properties and watervapor transmission characteristics of insulating materials. A standard sample (NBS) of fiberglass was used to test accuracy of instrument.

\section{SPECIMEN}

b) $69 \mathrm{~kg} / \mathrm{m}^{3}$ and $84 \mathrm{~kg} / \mathrm{m}^{3}$; c) air/atmospheric; h) moisture absorption.

\section{APPARATUS}

a) Refrigerated room/heat-flow meter; b) $60 \mathrm{~cm} \mathrm{sq.;} \mathrm{c)} \mathrm{vertical;}$

d) copper-constantan TC; e) heat-flow meter calibrated with hot-plate apparatus.

\section{DATA}

a) $10^{\circ} \mathrm{C}$; b) Table 1: Density, moisture absorption and thermal conductivity of 7 insulations.

For Glass wool $\left(69 \mathrm{~kg} / \mathrm{m}^{3}\right): \quad k=0.251 \mathrm{~mW} / \mathrm{cm} \cdot d e g$ at $\mathrm{T}_{\mathrm{m}}=10^{\circ} \mathrm{C}$ Fiberglass $\left(84 \mathrm{~kg} / \mathrm{m}^{3}\right): \mathrm{k}=0.216 \mathrm{~mW} / \mathrm{cm} \cdot \operatorname{deg}$ at $\mathrm{T}_{\mathrm{m}}=12^{\circ} \mathrm{C}$ 
[4] Allcut, E. A., An Analysis of Heat Transfer Through Thermal Insulating Materials, General Discussion on Heat Transfer, Sep. 1951, IME/ASME pp. 232235, 486-487 (Inst. Mech. Eng., London, 1951)

PURPOSE

Study influence of radiation and convection on heat transfer in fibrous insulation.

SPECIMEN

b) 1.25 to $3.51 \mathrm{~b} / \mathrm{cu} \mathrm{ft}\left(20\right.$ to $56 \mathrm{~kg} / \mathrm{m}^{3}$ ); c) air/0.4 to 80 in $\mathrm{Hg}$ ( 1.3 to $270 \mathrm{kPa}$ )

APPARATUS

a) guarded hot plate; b) 8 inches $(20 \mathrm{~cm})$; f) enclosed in pressure-vacuum tank

DATA

a) 34 to $96^{\circ} \mathrm{F} / 34$ to $62^{\circ} \mathrm{F}$ difference ( 1 to $36^{\circ} \mathrm{C} / 19$ to $34^{\circ} \mathrm{C}$ difference)

b) Table 1: $\mathrm{k}$ vs density for glass wool batts

2: $k$ vs $p$ for air cell

$3,4,5: \quad k$ vs $p$ vs for glass wool batts

6: \% of total heat transmitted by convection

Figure 1: $k$ vs density for various materials including mineral wool

2: $k$ vs cell size for Styrofoam

3: $k$ vs $p$ for various materials

4: $k$ vs p vs density for glass wool

5: $(p / k)$ vs $p$ for glass wool

6,8: convection vs $p$, and density for glass wool.

ANALYSIS

b) radiation effect is negligible in glass wool blankets exceeding $2 \mathrm{lb} / \mathrm{cu}$ $\mathrm{ft}\left(32 \mathrm{~kg} / \mathrm{m}^{3}\right)$ density; c) In cellular or granulated materials, $\mathrm{k}$ varies almo'st directly with cell size. 
[5] Allcut, E. A., Properties of Heat Insulating Materials, The Engineering Journal, 514-520 (Nov. 1941)

\section{PURPOSE}

A discussion of the character of heat insulating material, the difficulties in determining their relative value experimentally, the effect of air spaces and surface resistance and the possibility of saving fuel by taking advantage of solar radiation and heat stored in the structure of the building itself. An appendix describes a microscopic examination of a number of insulating materials.

\section{SPECIMEN}

a) 0.2 to 1.5 in ( 5 to $38 \mathrm{~mm})$; b) 1.6 to $51 \mathrm{~b} / \mathrm{cu} \mathrm{ft}\left(26\right.$ to $\left.80 \mathrm{~kg} / \mathrm{m}^{3}\right)$;
c) air/atmospheric;
e) $5.5 \mathrm{Hm}$

\section{APPARATUS}

a) guarded Hot Plate; b) 8 in $(20 \mathrm{~cm})$ square; c) vertical

\section{DATA}

a) $90^{\circ} \mathrm{F} / 35$ to $200^{\circ} \mathrm{F} /$ in $\left(32^{\circ} \mathrm{C} / 8\right.$ to $44^{\circ} \mathrm{C} / \mathrm{cm}$ )

b) Table 1: $k$ vs thickness (density) for three blanket materials (one glass wool).

Table 2: Heat loss in insulated pipes.

Figure 1,2: Structure of different fiber boards.

3: Air leakage in rock woo1

4: Air leakage in fiberboard, different densities.

6: $k$ vs air pressure for various materials

8: $k$ vs thickness

9: $k$ vs density

11: $\mathrm{k}$ vs thickness

14: fiber-diameter distribution curve. 
[6] Bankvall, C., Heat Transfer in Fibrous Materials, J. of Testing and Evaluation, JTEVA, 1(3), 235-243 (May 1973).

PURPOSE

Mechanisms of heat transfer are calculated theoretically, then verified experimentally by measurements on glass fiber insulation in a specially constructed guarded hot plate apparatus. The author claims the theories give a complete and consistent explanation of the influence of the mechanisms of heat transfer on the effective thermal conductivity of fibrous material.

SPECIMEN

a) 0.5 to $5 \mathrm{~cm}$; b) 15 to $80 \mathrm{~kg} / \mathrm{m}^{3}$; c) air $/ 10^{-3}$ to $760 \mathrm{~mm} \mathrm{Hg}$ (0.1 to $100 \mathrm{kPa})$; d) $5 \mu \mathrm{m}$; f) porosity, radiation coefficient.

APPARATUS

a) guarded hot plate, one-sided, rotatable;

b) $35 \mathrm{~cm} \mathrm{diam;}$

c) horizontal

THEORY

a) Fibers in layers at right angles to flow of heat; walls, fibers are "gray", non-transparent bodies; b) Two-phase open-pore model.

$\mathrm{k}_{\text {eff gas }}=\mathrm{k}_{\text {gas }} \frac{\mathrm{pL} \text { 。 }}{\mathrm{pL}+\mathrm{ET}}, \mathrm{L}_{\circ}=$ inter-fiber distance $=\pi \mathrm{D} / 4(1-\varepsilon)$

$\mathrm{k}_{\text {eq. }}$ fib $=32(1-\varepsilon)^{2}$ so $1 / \pi\left(3+\frac{\pi}{4(1-\varepsilon)}\right)$

$k_{\text {eff rad }}=4 \sigma \mathrm{LT}_{\mathrm{m}}^{3} /\left(\beta^{-1}+\mathrm{L}_{\circ}\left(2 / \varepsilon_{\circ}-1\right) / \mathrm{d}\right)=4 \sigma \mathrm{L} \circ \beta \mathrm{T}_{\mathrm{m}}^{3}$

$\frac{\text { DATA }}{\text { a) } 0}$ to $56^{\circ} \mathrm{C}$;

b) Figure 2: Open-pore two-phase mode1.

6: Radiation coefficient, $\beta$, vs porosity, $\varepsilon$.

7: $k_{f i b} v s$ porosity

8: $\beta$ vs $\varepsilon$ for different temperatures.

9: Structural parameter, $\alpha$, vs porosity, $\varepsilon$.

10: $\varepsilon_{\mathrm{s}}$ vs $\varepsilon$.

11: Radiational conductivity vs specimen thickness.

12: $\mathrm{k}$ vs $\mathrm{T}_{\text {mean }}$ for $\mathrm{d}=16.4 \mathrm{~kg} / \mathrm{m}^{3}$, low $\left(10^{-3} \mathrm{~mm} \mathrm{Hg}\right)$ pressure.

13, 14: $\mathrm{k}$ vs pressure. $\mathrm{T}_{\mathrm{m}}=30^{\circ} \mathrm{C}, \mathrm{d}=16.4$ and $78.6 \mathrm{~kg} / \mathrm{m}^{3}$

15: $\mathrm{k}$ vs $\mathrm{T}_{\mathrm{m}}$ at atmospheric pressure.

16: Mechanisms of heat transfer in glass fiber.

ANALYSIS

c) All mechanisms involved in transfer by gas must be considered, to be correct in estimating contribution by gas to $k_{e f f}$ d) Conduction in gas contributes largest part of $\mathrm{k}_{\text {eff }}$ in range $15-80 \mathrm{~kg} / \mathrm{m}^{3}$. Radiation is of greatest importance at low density and leads to large $\mathrm{k}$ at low density. Conduction of solids is an important contribution at high density. Increasing temperature leads to larger $k$, especially at low density where radiation is important. 
[7] Bartoli, R. and Laine, P., Thermal Conductivity Measurements of Fiberglass Panels at Different Temperatures in Various Atmospheres, Supplement to Bull. of Int' 1 Institute of Refrig. (Paris) Annexe 1956-2, pp. 233-240 (1956).

\section{PURPOSE}

Measurements of Thermal Conductivity of Fiberglass panels in various gases, at different temperatures.

\section{SPECIMEN}
a) $5 \mathrm{~cm}$;
b) $33,88,120 \mathrm{~kg} / \mathrm{m}^{3}$;
c) air, $\mathrm{CO}_{2}, \mathrm{R}-12$;
d) $12 \times 10^{-6} \mathrm{~m}$;
e) none

\section{APPARATUS}

a) guarded hot plate; c) horizontal; d) copper-constantan TC's

DATA

a) -15 to $+15^{\circ} \mathrm{C} / 26$ to $66 \mathrm{~K} / \mathrm{cm}$

b) Figures 2,3,4: vs $\mathrm{T}$, several densities

$$
\begin{array}{rll}
\text { air: } & \mathrm{k}_{1}=(33.8+0.208 \mathrm{t}) \times 10-3 \mathrm{kCal} / \mathrm{m} \cdot \mathrm{h} \cdot{ }^{\circ} \mathrm{C}, & \mathrm{d}_{1}=33 \mathrm{~kg} / \mathrm{m}^{3} \\
\mathrm{k}_{2}=(26.8+0.145 \mathrm{t}) \times 10-3 & \mathrm{~d}_{2}=88 \mathrm{~kg} / \mathrm{m}^{3} \\
\mathrm{k}_{3}=(26.3+0.120 \mathrm{t}) \times 10-3 & \mathrm{~d}_{3}=120 \mathrm{~kg} / \mathrm{m}^{3} \\
\mathrm{CO}_{2}: & \mathrm{k}_{1}=(23.6+0.185 \mathrm{t}) \times 10-3 & \\
\mathrm{k}_{2}=(18.3+0.080 \mathrm{t}) \times 10-3 & & \\
\mathrm{R}-12: & \mathrm{k}_{2}=(12.0+0.100 \mathrm{t}) \times 10-3 &
\end{array}
$$

\section{ANALYSIS}

a) At $0^{\circ} \mathrm{C} \quad \frac{\mathrm{k}_{1}\left(\mathrm{CO}_{2}\right)}{\mathrm{k}_{1}(\mathrm{air})}=0.70, \frac{\mathrm{k}_{2}\left(\mathrm{CO}_{2}\right)}{\mathrm{k}_{2}(\mathrm{air})}=0.69, \frac{\mathrm{k}_{2}\left(\mathrm{R}_{12}\right)}{\mathrm{k}_{2}(\mathrm{air})}=0.45$

in good agreement with Verschoor and Greebler, $(0.71,0.71,0.47$, resp.) at $\mathrm{T}_{\mathrm{m}}=66^{\circ} \mathrm{C}$.

$$
\text { and } \begin{aligned}
\mathrm{k}_{1 \mathrm{~g}}(\text { air }) & =(20.8+0.060 \mathrm{t}) \times 10^{-3} \mathrm{kCal} \times \mathrm{mm} \cdot \mathrm{h} \cdot{ }^{\circ} \mathrm{C} \approx \mathrm{k}_{2 \mathrm{~g}} \approx \mathrm{k}_{3 \mathrm{~g}} \\
\mathrm{k}_{1 \mathrm{c}}(\text { air }) & =(13.0+0.148 \mathrm{t}) \times 10^{-3} \mathrm{kCal} \times \mathrm{mm} \cdot \mathrm{h} \cdot{ }^{\circ} \mathrm{C} \\
\mathrm{k}_{2 \mathrm{c}}(\text { air }) & =(5.55+0.084 \mathrm{t}) \times 10^{-3} \mathrm{kCalxm} \cdot \mathrm{h} \cdot{ }^{\circ} \mathrm{C} \\
\mathrm{k}_{3 \mathrm{c}}(\text { air }) & =(4.75+0.058 \mathrm{t}) \times 10^{-3} \mathrm{kCal \times m} \cdot \mathrm{h} \cdot{ }^{\circ} \mathrm{C}
\end{aligned}
$$


[8] Brendeng, E. and Frivik, P. E., New Development in Design of Equipment for Measuring Thermal Conductivity and Heat Flow, Heat Transmission Measurements in Thermal Insulations, ASTM-STP 544, pp. 147-166 (1974).

PURPOSE

This paper describes some of the recent developments in test equipment design and operation.

SPECIMEN

a) $10 \mathrm{~cm}$; b) $11,88 \mathrm{~kg} / \mathrm{m}^{3}$; c) air/atmospheric; f) temperature distribution; influences of convection, emissivity of plates.

APPARATUS

a) guarded hot plate; b) $0.4 \mathrm{~m} \mathrm{sq} \cdot$; c) horizontal; d) PRT and TC's;

e) measured reference material calibrated at National Physical Laboratory (England)

DATA

a) -5 to $80^{\circ} \mathrm{C}$

b) Figure 8: $\mathrm{k}$ vs $\mathrm{T}_{\mathrm{m}}$, glass wool and glass fiberboard, 11 and $88 \mathrm{~kg} / \mathrm{m}^{3}$ 9B: keff vs $\Delta \mathrm{T}$, glass wool 
[9] Christiansen, R. M. and Hollingsworth, M., Jr., The Performance of Glass Fiber Insulation Under High Vacuum, Advances in Cryogenic Engineering, 4, 141-153 (Plenum, New York, 1960).

\section{PURPOSE}

Evaluate technique of partial removal of fill gas from fibrous insulation to improve thermal performance. Study effective thermal conductivity vs pressure, density and fiber diameter.

\section{SPECIMEN}

a) $0.2-1.8$ in. ( 5 to $45 \mathrm{~mm}$ ); b) $0.5-151 \mathrm{~b} / \mathrm{cu} \mathrm{ft}\left(8\right.$ to $240 \mathrm{~kg} / \mathrm{m}^{3}$ ); c) air $/ 2 \cdot 10^{-4} \mathrm{~mm} \mathrm{Hg}$ to $1 \mathrm{~atm}(0.03$ to $100 \mathrm{kPa})$; d) $22,45,135,480$

micro-inches $(0.55,1.12,3.38,12 \mu \mathrm{m})$; e) heat felting or phenolic resin

\section{APPARATUS}

a) heat meter in bell jar; b) 12 in (30 cm) sq; c) vertical; d) differential TC; e) samples of known conductivity

DATA

a) $75^{\circ} \mathrm{F} / 35$ to $200^{\circ} \mathrm{F} / 1 \mathrm{n}\left(24^{\circ} \mathrm{C} / 8\right.$ to $\left.44^{\circ} \mathrm{C} / \mathrm{cm}\right)$;

b) For a density of $41 \mathrm{~b} / \mathrm{ft}^{3}$ :

$\mathrm{k}($ resid. gas + sol. $)=0.0037, \mathrm{k}(\mathrm{rad})=0.0065$ at $\mathrm{T}_{\mathrm{m}}=75^{\circ} \mathrm{F}\left(24^{\circ} \mathrm{C}\right)$

$\mathrm{k}(\mathrm{resid} \cdot \mathrm{gas}+\mathrm{sol} \cdot)=0.0018, \mathrm{k}(\mathrm{rad})=0.0016$ at $\mathrm{T}_{\mathrm{m}}=-180^{\circ} \mathrm{F}$

$\left(-118^{\circ} \mathrm{C}\right)$

ANALYSIS

a) Figure 4: $k$ vs pressure (vs fiber diam. vs density)

6: $k$ vs fiber diam. (vs density, pressure)

7: Importance of insulation in blocking radiation

9: component separations

c) For $0.1 \mathrm{~mm} \leq \mathrm{p} \leq 100 \mathrm{~mm} \mathrm{Hg}(0.01$ to $13 \mathrm{kPa})$, finer fiber and higher density give 1ower $k$.

At low density and high p, optimum fiber diam. is $5010^{-6}$ in $(130 \mu \mathrm{m})$.

At low p, higher density not harmful.

Mean free path and average fiber spacing control k.

Optimum density $8 \mathrm{lb} / \mathrm{cu} \mathrm{ft}\left(130 \mathrm{~kg} / \mathrm{m}^{3}\right)$ at vacuum, $41 \mathrm{~b} / \mathrm{cu} \mathrm{ft}\left(60 \mathrm{~kg} / \mathrm{m}^{3}\right)$ at atmospheric pressure.

Existence of optimum fiber diameter, predicted by Larkin, confirmed, because at very low $\mathrm{p}, \mathrm{k}$ (res) is due to radiation and solid conduction. When fiber insulation is present at moderately low pressure $(0.1 \mathrm{~mm}$, $13 \mathrm{~Pa}) \mathrm{k}$ is as low as in high vacuum. Fiber insulation necessary to block radiation between surfaces. 
[10] Codegone, C., Ferro, V., and Sacchi, A., Studies on Heat Transfer in Refrigeration (Proc. of IIR, Comm. 2, 1966) Pergamon Press, Ltd., Oxford, 23-37 (1966).

Purpose

Thermal insulating material made up of fiberglass was tested at temperatures to $-190^{\circ} \mathrm{C}$ in order to study convective effects.

SPECIMEN
a) $15 \mathrm{~cm}$ radially;
b) $75 \mathrm{~kg} / \mathrm{m}^{3}$;
c) dry $\mathrm{N}_{2}$ /atmospheric;
d) $6 \mu \mathrm{m}$

APPARATUS

a) cylindrical, calorimetric method, guarded; b) $180 \mathrm{~cm}$ long $\mathrm{x} 20 \mathrm{~cm}$ diameter $/ 60 \mathrm{~cm}$ long; c) horizontal; d) copper constantan thermocouple

THEORY

a) circular isothermal distribution assumed in finding $k$ equation

DATA

$\overline{\text { a) }}^{\circ}$ to $-190^{\circ} \mathrm{C}$, one gradient from $0^{\circ}$ to $-190^{\circ}$ over $15 \mathrm{~cm}$ radially;

b) Table $2-k$ vs T, Figure $9-\mathrm{k}$ vs T, $\mathrm{k}=4.196 \times 10^{-2}+1.973 \times 10^{-4} \mathrm{t}+$ $3.719 \times 10^{-8} \mathrm{t}^{2}\left[\mathrm{~W} / \mathrm{m}^{\circ} \mathrm{C}\right]$

ANALYSIS

a) results compared to those in a square plate apparatus; b) effect of convection studied; c) the values in the cylindrical apparatus are 20-40\% higher than those in the square plate apparatus due to convection enhancement of heat flow. 
[11] Finck, J. L., Mechanism of Heat Flow in Fibrous Materials, J. of Res. of N.B.S. 5 . 973-984 (1930).

\section{PURPOSE}

Made a systematic study of thermal conductivities of fibrous materials showing effects of packing density, fiber arrangement, moisture, convection and radiation of conduction.

SPECIMEN
a) 1 in.
$(2.5 \mathrm{~cm})$;
b) $0.16 \mathrm{~g} / \mathrm{cm}^{3}$;
c) air/atmospheric

\section{APPARATUS}
a) flat hot plate;
b) 8 in $(20 \mathrm{~cm}) \mathrm{sq}$
c) vertical

DATA

a) $32^{\circ} \mathrm{C} / 30^{\circ} \mathrm{C} /$ in $\left(12^{\circ} \mathrm{C} / \mathrm{cm}\right)$; b) all data reduced to value at $t=32^{\circ} \mathrm{C}$ by $k_{t}=k_{32}[1+(t-32)],=0.0032$, as found by averaging over values for numerous materials; d) $2 \%$

Table I: $k_{32}$ vs density for 21 fibers including asbestos (almost all vegetable fibers);

II: $k_{32}$ vs density for 3 fibers at $53 \%$ Re1. Hum.

III: $k_{32}$ vs density for fiber mixtures

IV: $k_{32}$ vs fiber arrangement

V: Selected fibers are chosen to study effects of convection and radiation

Figure 1: $k_{32}$ vs density

2: $k_{32}$ vs density: dry and moisture-conditioned

\section{ANALYSIS}

c) For a given fibrous material and a given density, the conductivity may vary by several hundred per cent, depending entirely on the arrangement of the fibers. The maximum conductivity is obtained when the fibers are parallel to and the minimum conductivity is obtained when the fibers are perpendicular to the direction of heat flow. 
[12] Lander, R. M., Gas is an Important Factor in the Thermal Conductivity of Most Insulating Materials, Part II, ASHVE Transactions, 151-168 (1955).

PURPOSE

Describes investigation of the reduction in thermal conductivity of common insulating materials by replacing air with gases of larger molecular weight or fill gas.

SPECIMEN

a) 1 in $(2.5 \mathrm{~cm})$; b) $0.58,0.78,1.94,3.801 \mathrm{~b} / \mathrm{ft}^{3}\left(9,12,31,61 \mathrm{~kg} / \mathrm{m}^{3}\right)$;

c) Air, $\mathrm{Co}_{2}, \mathrm{R}-12 / 0.1 \mu \mathrm{m}$ of $\mathrm{Hg}$ to 1 atm $(0.01$ to $100 \mathrm{kPa})$

\section{APPARATUS}
a) guarded hot plate;
b) 12 in $(30 \mathrm{~cm})$ square;
c) vertical;
d)
thermocouples

DATA

a) $100^{\circ} \mathrm{F}$ mean, $50^{\circ} \mathrm{F} /$ in $\left(38^{\circ} \mathrm{C}, 11^{\circ} \mathrm{C} / \mathrm{cm}\right)$

b) Table 1: $k$ vs fill gas; $k(a i r)$ vs $p ; \%$ reduction in heat transfer due to gas substitutions

2: $k$ vs $\mathrm{p}$ for air, $\mathrm{CO}_{2}, \mathrm{R}-12$

3: k vs \% mixture of $\left(\mathrm{CO}_{2}, \mathrm{R}-12\right)$ with air

4: $k$ vs $T$ for various gases/densities

5: Calculated Different Modes of Heat Transfer for three densities, three gases, vs $\mathrm{T}$.

Figure 7: k vs $\mathrm{T}$ for glass wool in air, $\mathrm{CO}_{2}, \mathrm{R}-12$ for varying insulation densities

9: Gas transferred heat vs $\mathrm{T}$ for various fill gases

11: Heat transferred by radiation/conduction vs density for various $T^{\prime}$ 's.

ANALYSIS

b) fiber conduction/gas transferred heat (conduction)/radiation

c) Major mode of heat transfer is by the fill gas

18 to $31 \%$ reduction in $\mathrm{k}$ if $\mathrm{CO}_{2}$ replaces air

28 to $56 \%$ reduction in $\mathrm{k}$ if $\mathrm{R}-12\left(\mathrm{CF}_{2} \mathrm{Cl}_{2}\right)$ replaces air

Conductivity of glass wool is decreased for increasing density (amount of decrease independent of fill gas).

For practical insulation, radiation is an important mode of heat transfer - conduction through fibers is negligible.

Convection not important except for large volumes of low density insulation. 
[13] Tye, R. P., Measurements of Heat Transmission in Thermal Insulations at Cryogenic Temperatures Using the Guarded Hot Plate Method, Prog. in Refrig. Sc1.\& Techn. 1, Proc. XIII Int'l Conf. of Refrig., Wash., DC, pp. 371-378 (1970).

\section{PURPOSE}

Has measured heat transmission in a number of different thermal insulations, using a guarded hot plate. Looked at influence of vacuum on vermiculite.

SPECIMEN

a) $25 \mathrm{~mm} ; \quad$ b) $183.5 \mathrm{~kg} / \mathrm{m}^{3}$; c) $\mathrm{dry} \mathrm{N} / 7 \cdot 10^{-5}$ to 760 torr $\left(10^{-5}\right.$ to $\left.100 \mathrm{kPa}\right)$

\section{APPARATUS}

a) guarded hot plate; b) $20 \mathrm{~cm}$ diam.; c) horizontal;

d) copper-constantan $\mathrm{TC}$ 's

DATA

a) 100 to $300 \mathrm{~K} / 15$ to $60 \mathrm{~K} /$ in $(6$ to $24 \mathrm{~K} / \mathrm{cm}$ )

b) Table 1: Details of 11 different specimens

2: $k$ of vermiculite vs pressure

Figure 1: $k$ of cellular plastic insulations

2: $k$ of various insulation

c) $\pm 3 \%$ 
[14] Wilkes, G. B., Thermal Conductivity, Expansion and Specific Heat of Insulators at Extremely Low Temperatures, Refrig. Eng • 52(1), 37-42, 68-72 (July 1946).

PURPOSE

The thermal conductivity of several types of low temperature insulation has been determined for temperatures ranging from $170^{\circ} \mathrm{F}$ to $-300^{\circ} \mathrm{F}$. The conductance of one type of reflective insulation has been investigated for the horizontal position, heat flowing upward and downward. The results for the reflective insulation indicate that the conductance with downward heat flow varies with the mean temperature while with upward flow it varies with the temperature difference and is independent of the mean temperature except for very small temperature differences. Three distinctly different methods of determining the conductance were used in these tests.

SPECIMEN

a) 1,2 in. $(2.5,5 \mathrm{~cm})$; b) $11 \mathrm{lb} / \mathrm{cu} \mathrm{ft}\left(176 \mathrm{~kg} / \mathrm{m}^{3}\right)$; c) dry air/ atmospheric; f) specific heat, thermal expansion, thermal diffusivity

APPARATUS

a) guarded hot plate; b) $7 \mathrm{in} / 4$ in $(18 \mathrm{~cm} / 10 \mathrm{~cm})$ test diameter; c) horizontal; d) copper-constantan TC; f) heat power determined by gas evolution

DATA

a) $-111,-16,119^{\circ} \mathrm{F} / 76-316^{\circ} \mathrm{F} /$ in $\left(-79,-27,84^{\circ} \mathrm{C} / 17-70^{\circ} \mathrm{C} / \mathrm{cm}\right) ; \quad$ b) calculated $\mathrm{k}$ for values of actual temperature as compared to $\mathrm{T}_{\mathrm{m}}$.

Table 1: $k$ vs $T$ for selected insulating materials

3: Spec. ht. and thermal diffusivity vs $\mathrm{T}_{\mathrm{m}}$

4: Thermal expansion vs $\mathrm{T}_{\mathrm{m}}$

Figure 6: mean $\mathrm{k}$ vs mean $\mathrm{T}$

7: $\mathrm{k}$ vs $\mathrm{T}$

12, 13: mean spec. ht. vs $T$

14: thermal diffusivity vs $\mathrm{T}_{\mathrm{m}}$

17: thermal expansion vs $\mathrm{T}_{\mathrm{m}}$

18: \% change in length vs $\mathrm{T}_{\mathrm{m}}$ 
[15] Wilson, F. C., Evacuated and Gas-filled Insulation Systems, Refrig. Eng., pp. 57-60, 102, (Apr. 1957).

\section{PURPOSE}

Study effective thermal conductivity in fibrous glass insulation vs species of fill gas, gas pressure, fiber diameter.

\section{SPECIMEN}

b) $1,2,9.7,10.91 \mathrm{~b} / \mathrm{cu}$ ft $\left(16,32,155,174 \mathrm{~kg} / \mathrm{m}^{3}\right)$; c) $\mathrm{R}-12, \mathrm{CO}_{2}$, Ne at atmospheric, air at $10 \mu \mathrm{m} \mathrm{Hg}$ to 1 atm $\left(10^{-3}\right.$ to $\left.100 \mathrm{kPa}\right)$; d) $27,150,350,500,600$, micro inches $(0.68,4,9,12,15 \mu \mathrm{m})$; e) none; f) two gas mixtures: $\mathrm{H}_{2}-\mathrm{CO}_{2}$ and $\mathrm{R}-12-\mathrm{air}$.

\section{APPARATUS}

a) guarded hot plate; b) specimen in thin bags enclosing fill gas, or apparatus in steel vacuum tank

DATA

a) $75-150^{\circ} \mathrm{C}$;

b) Tables I-III: $k$ vs fill gas species at three mean temperatures, four fiber diameters and four densities:

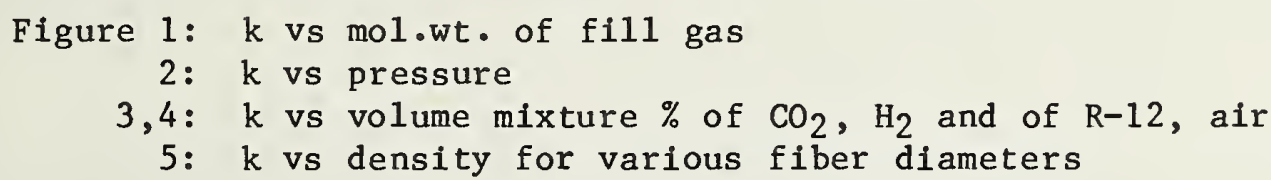

ANALYSIS

c) to reduce thermal conductivity by choice of fill gas, use any mol.wt. $\geq 50 . k$ is greater for coarser fibers

$k$ is at residual level for $p<0.01 \mathrm{~mm}$ of $\mathrm{Hg}(1 \mathrm{~Pa})$

$\mathrm{k}$ increases less than linearly from value for high-mol.wt. fill gas when diluted (air)

Optimum density for $150 \mathrm{micro-inch}(4 \mu \mathrm{m}) \mathrm{fiber}$ is $2.51 \mathrm{~b} / \mathrm{cu}$ ft $\left(40 \mathrm{~kg} / \mathrm{m}^{3}\right)$. 
[16] Zabawsky, Z., An Improved Guarded Hot Plate Thermal Conductivity Apparatus with Automatic Controls, ASTM Symposium on Thermal Conductivity Measurements, STP No. $217,3-17$ (1957).

\section{PURPOSE}

To describe an apparatus constructed according to ASTM Standard C177-45 but with additional changes to allow measurement of $k$ within $1 \%$ of values determined by the National Bureau of Standards.

SPECIMEN

a) 0.5 to 1.5 in (13 to $38 \mathrm{~mm})$; b) $9.6,15.7$, and $68.2 \mathrm{~kg} / \mathrm{m}^{3}$

APPARATUS

a) guarded hot plate; c) horizontal; d) thermocouples; f) heater to guard $\pm 0.004^{\circ} \mathrm{F}\left(0.002^{\circ} \mathrm{C}\right)$, cold plate control $\pm 0.05^{\circ} \mathrm{F}\left(0.03^{\circ} \mathrm{C}\right)$, reproducibility $\pm 0.5 \%$.

TATA

a) $60-110^{\circ} \mathrm{F}$ ( 16 to $43^{\circ} \mathrm{C}$ ); b) Fig. $14 \mathrm{k}$ vs $\mathrm{T}$ for three fiberglass materials 
NBS.114A (REV. 2-80)

U.S. DEPT. OF COMM.

BIBLIOGRAPHIC DATA

SHEET (See instructions)

4. TITLE AND SUBTITLE

1. PUBLICATION OR
REPORT NO.
NBSIR $80-1639$

2. Performing Organ. Report No.

3. Publication Date

February 1981

Effective Thermal Conductivity of a Glass Fiberboard Standard Reference Material

5. AUTHOR(S)

Dr. D. R. Smith and J. G. Hust

6. PERFORMING ORGANIZATION (If joint or other than NBS, see instructions)

7. Contracd Grant No.

NATIONAL BUREAU OF STANDARDS

DEPARTMENT OF COMMERCE

WASHINGTON, D.C. 20234

8. Type of Report \& Period Covered

9. SPONSORING ORGANIZATION NAME AND COMPLETE ADDRESS (Street, City, State, ZIP)

Department of Energy

Oak Ridge Operation

Oak Ridge, TN 37830

(Under Interagency Agreement DoE No. DE-AI05-780R05965)

10. SUPPLEMENTARY NOTES

Document describes a computer program; SF-185, FIPS Software Summary, is attached.

11. ABSTRACT (A 200-word or less factual summary of most significant information. If document includes a significant bibliography or literature survey, mention it here)

This paper describes the results of thermal conductivitymeasurements on NBS SRM 1450 glass fiberboard insulation (1970 lot) at temperatures from $87 \mathrm{~K}$ to $340 \mathrm{~K}$. The measurements were performed in an atmosphere of dry nitrogen at a pressure near $84 \mathrm{kPa}(630 \mathrm{~mm} \mathrm{Hg})$. The results are analyzed and compared to NBS certification data and to literature data for similar material. An annotated bibliography of literature sources is included.

12. KEY WORDS (Six to twelve entries; alphabetical order; capitalize only proper names; and separate key words by semicolons)

Glass fiberboard; insulation; low-temperature; standard reference material; thermal conductivity.

13. AVAILABILITY

[\%] Unlimited

For Official Distribution. Do Not Release to NTIS

$\square$ Order From Superintendent of Documents, U.S. Government Printing Office, Washington, D.C. 20402.

X Order From National Technical Information Service (NTIS), Springfield, VA. 22I6I

14. NO. OF PRINTED PAGES

\section{4}

15. Price

$\$ 6.50$ 
, 

